\title{
Interviewing for research on languages and war ${ }^{1}$ \\ Catherine Baker \\ University of Hull
}

Pre-print of chapter in The Palgrave Handbook of Lasnguages and Conflict, ed. Michael Kelly, Hilary Footitt and Myriam Salama-Carr (London: Palgrave Macmillan, 2019)

Every participant in war encounters war through its languages. Languages are the basic ingredients of many of the sights and soundscapes of war, whether troops and civilians encounter them as temporary sojourners in a foreign territory or whether war is taking place on soil they regard as home: from the slang and patois with which foreign soldiers have learned to communicate with local civilians to go about the business of everyday life, to the 'weaponization' (Rafael 2012) of language through counter-insurgency and interrogation, to the impressions that the very perceptibility of linguistic difference in itself can leave on individuals' experiences of war - consider how often the adhan or Islamic call to prayer, in Arabic, became 'the most striking and memorable non-weapon-related sound' for so many coalition soldiers deployed to Iraq and Afghanistan during the War on Terror (Daughtry 2015: 58), or how the designers of simulated environments on military training ranges commonly use foreign languages, signs and scripts to communicate the practical and symbolic implications of linguistic difference to troops before they deploy (peacekeepers in Bosnia who did not read Cyrillic script, for instance, could not count on being able to read place names from all road signs).

In certain wars, especially ethnopolitical conflicts such as the Yugoslav wars of the 1990s and their aftermath, the matter of which languages are present or absent, and in what form, is part of the war itself: an armed force taking control of territory and claiming it as part of a historical national homeland, to the exclusion of competing claims, will strengthen its claim by driving out the language(s) as well as the individual members of the group(s) it considers a minority, while an army of occupation pursuing irredentist war aims, like Italy occupying the Julian Alps in 1915-17, will likewise impose its national language across public space in extending the power of the occupying state and assimilating those minorities who remain under its authority (Svoljšak 2012). Such instances of language as war, not just language in war, are ruptures in the very fabric of everyday life for inhabitants of the region, and symbolic politics that foreign interveners, during their involvement in the conflict, may or may not strive to understand.

Most participants in war have also encountered war through the mediations of meaning between languages (written translation and spoken interpreting) that occur at every stage of planning, warfighting and peacemaking yet until recently went largely unnoticed in the wider study of war. Even in wars where troops have not been deployed abroad and the languages spoken by each side are the same, experiences of war raise the question of 'translation' between military and civilian registers and vocabularies: indeed, they pose the thorny literary question of whether embodied wartime experiences can be adequately 'translated' at all through language that conveys them to readers and listeners who do not have the same embodied memories of the sensations of war (see Baker 2016; Dyvik 2016). Many past and

\footnotetext{
${ }^{1}$ This chapter owes much to conversations with the Languages at War research team (Louise Askew, Hilary Footitt, Michael Kelly, Greg Tinker, Simona Tobia) in 2008-12 and with fellow feminist researchers of war and the military since then such as Victoria Basham, Sarah Bulmer, Amanda Chisholm, Synne Dyvik, Harriet Gray, and Alexandra Hyde. I am particularly grateful to Rachel Woodward for bringing her research with Neil Jenkings on military memoirs to a life history and life writing conference at Sussex in 2010 and enabling us both to realise that an oral history and translation studies project could also speak to military sociology and geography.
} 
present wars, as contributors to this handbook have done much to show, have involved militaries which are themselves the forces of multilingual empires, multi-ethnic nations or part of multilingual coalitions, each with their own official and unofficial policies about languages of instruction and command and their own negotiations about where and how internal mediation between languages occurs.

Putting both languages themselves and language mediation into the centre of the study of war - as many chapters in this volume seek to do - brings to that centre not only the interlinguistic and intercultural encounters that occur before, during, after and on the margins of war, but also categories of people whose roles in war have often gone unnoticed because of the historic 'invisibility' (Venuti 2008) of the translator. Acting as a language intermediary in time of war blurs certain distinctions between military and civilian while reinforcing others - from civilian translators and interpreters (recruited from the conflict zone or a foreign force's home state) who may live and work on a foreign force's base and wear its uniform, to those trained soldiers whose skills as linguists leave them spending much of their time in the conflict zone performing tasks they might not have associated with war. Since such roles are so often on the margins of the typical categories of experience through which many people thinking about war, they can be difficult to trace through archival methods as historical phenomena, while in a contemporary setting their very nature means that they do not lend themselves well to observational methods. The memories of language intermediaries - and indeed of participants in and witnesses to war in general whose experiences of conflict have also been experiences of language - may, on the other hand, lend themselves to research through interview. Indeed, interviewing may sometimes be the only method for getting as close as possible to such memories - though how close it is ever possible to get is the major interpretive question of this chapter.

I began using interviews to research languages and war as a postdoctoral researcher on the AHRC-funded 'Languages at War' project in 2008-11, which contained a case study (led by Michael Kelly) on languages and peacekeeping during and after the war of 1992-5 in BosniaHerzegovina (BiH). ${ }^{2}$ In 2009-10, I conducted more than 50 interviews with ex-peacekeepers (mostly British, though some Danish), Anglophone civilian language professionals who had worked for the British military or the North Atlantic Treaty Organization (NATO), and (what turned out to be the largest category of interview participants in the project) former or still active locally-recruited language intermediaries from the Yugoslav region who had worked for foreign military forces in $\mathrm{BiH}$. Each interview lasted between 1 and 3.5 hours, depending on how expansively the interviewee answered questions, with most between 90 minutes and 2 hours: a typical transcript could contain 15,000 words of text. Interviews could be invaluable sources of information about working environments that had been disbanded years ago and about the complex process of figuring out what language support for a foreign peacekeeping force during ethnopolitical conflict and post-conflict peacebuilding might entail. They were also narratives produced in interaction and negotiation between each speaker and myself as the interviewer, and which were being produced moreover at a particular historical moment: a time of political stagnation in $\mathrm{BiH}$ and deepening financial crisis in the UK, refractions of a broader crisis of neoliberal capitalism in Europe. As such, they were simultaneously artefacts of oral history, a field where the interpretive work of interviewing is more complex but also even more rewarding than it can initially seem, and examples of the complicated negotiations of positionality between interviewer and interviewee that exist in any interview but take on even further dimensions in war-related research.

\footnotetext{
${ }^{2}$ The case study's original focus was 1995-8, matching the time frame of a parallel study on the Allied liberation and occupation of Western Europe (1944-7) - but in practice extended backwards to the beginning of the war in 1992, and forwards into the 2000s, to incorporate the time frames in which our interviewees had experienced changes in language practice (Kelly and Baker 2013).
} 
The inescapable dual function of interviews - as apparent record of previously unknown information and personal experience, and contingent product of memory that filters recollections of the past through a speaker's self-presentation years later - is what creates not only the drawbacks but also the unique richness of interviewing as a methodology. The insights that language researchers such as Siobhan Brownlie (2017) and Simon Coffey (2010) have been able to gain into spheres of linguistic activity that have some overlap with the typical domains of languages and war, such as institutional translation (in the European Commission's translation service) or language education, come from their awareness of the dynamics of memory. Brownlie (2017: 13), interviewing translators in a European institution, situates memory both at the point of narrative production and - as translators recirculate the 'memorial values' with which the institution was founded through the texts they translate - in the work of translation itself; her wider argument that Translation Studies and Memory Studies deserve to inform each other much more deeply since '[1]anguage and memory are intimately bound together' (Brownlie 2017: 1), supports this chapter's suggestion that researchers who use interviews to study language, translation or interpreting - or of course war itself - need to understand the complexities of remembering that Memory Studies and the field of oral history show.

Another illustration of what interviews can contribute to languages research comes from Simon Coffey's research with British adult learners of French. Coffey treats the interviews as autobiographical narratives of how each learner's subjectivity and their growing affinity for France and French culture had developed across time until they chose to make the commitment to learn French (indeed, before the interviews he asked participants to write a language learning autobiography that would then guide their interview). Establishing the speakers' narrative positions, and the discourses they used to construct them, showed Coffey (2010: 125) that his interviewees typically viewed Frenchness and France both as an 'aesthetic ideal', based on collective British cultural narratives about Anglo-French difference, and as a 'place of encounter [and ...] personal transformation', that is, a site for a more individualised change in subjectivity. These personal accounts, in other words, could not only illustrate the content of the 'shared cultural repertoires of the appeal of French' that circulated in 2000s Britain, but could suggest how individuals incorporate cultural imaginaries like these into the construction of their own personal identity.

While analysing the Languages at War interviews, I used a similar interpretive approach to Coffey's as one strand of my methodology by reading the interviews (especially those of foreign military personnel and civilians who had travelled to $\mathrm{BiH}$ ) as travel narratives. Many interview accounts of languages and war, where speakers have deployed abroad or otherwise engaged in foreign travel, can be approached as travel narratives (Woodward and Jenkings 2012) - and indeed the interviewer may often co-produce a travel narrative (I did) in asking establishing questions such as 'Do you remember what it was like when you first arrived in Bosnia?' in the course of guiding a speaker's process of remembering along. Critical literature on travel writing and representations of 'the Balkans' (see Goldsworthy 1998; Hammond 2007; Todorova 2009) with which I was familiar from previous research had identified recurrent tropes in European and Anglophone travel narratives about what the Balkans were and what European travellers had licence to do there, which (similarly to the dynamics of Orientalism) produced a cultural identity for 'Europe' by defining it against the Balkans and created a symbolic spatial hierarchy where the Balkans existed as a wild space in which civilised, urban Europeans could have adventures more than as a space with their own politics and agency. Drawing on this literature, I could then ask how far the tropes and 
conventions of published and broadcast travel narratives seemed to shape the narrative and interpretive positions that speakers took, versus how and where speakers were able to narrate their experience beyond the framework of these cultural scripts and produce accounts where the micropolitics of the site and time of travel seemed more perceptible (Baker 2011). Like the geographers Rachel Woodward and Neil Jenkings (2011; 2012), whose research on the wars in Iraq and Afghanistan has analysed both published memoirs and their own interviews, this part of the research was able to start exploring the circuit between cultural production, personal remembering, and individuals' narratives of identity as presented in an interview setting.

Scholars working both on languages and translation (Baker 2006), and in international relations and security studies (Wibben 2011), have argued that narrative approaches have much to offer the study of war and conflict, while suggesting also that any individual interview introduces deeper collective contexts and cultural scripts around what speakers present as memories of their experiences. For Mona Baker, calling for more narrative-based approaches to identity and conflict in Translation Studies, narrative theory is both able to demonstrate 'that people's behaviour is ultimately guided by the stories they come to believe about the events in which they are embedded' and to leave conceptual space for individuals' narratives, frames of perception and beliefs to change - sometimes constructively and sometimes less so - as they encounter new experiences (Baker 2006: 3). The feminist security studies scholar Annick Wibben complements this by providing a narratology-based critical apparatus for narratives that explicitly or implicitly construct ideologies of security which lets researchers question the narrative's assumptions about who or what is being threatened, who or what embodies the threat, whose role it is to protect them from it and how (Wibben 2011: 52). Bringing these assumptions to the surface, through narratological techniques such as interrogating the narrative order of events and determining from whose perspective (or 'focalization') a narrative is presented, reveals the gendered and racialised politics of international security. Feminist methodologies and epistemologies in international relations may, indeed, be particularly useful for researching languages and war, since one of their key disciplinary interventions is to make visible the kinds of experiences and participants in war that a military history centred on combat operations would downplay (Sylvester 2013). At the same time, however, the specific context of the research interview produces its own characteristic dynamics of remembering, self-presentation and narration, and these have been described particularly well in oral history.

War has provided the backdrop for many oral history projects, large and small, from the collections of tens of thousands of interviews built up over decades by an institution such as the Imperial War Museum (IWM) Sound Archive (partners in the original Languages at War project) to the studies through which oral historians such as Alistair Thomson (1994) or Penny Summerfield (1998) have explored ideas about the relationship between individuals' narrated memories of being embedded in the structures of armed conflict, on one hand, and public narratives of those same wars and their place in the collective (especially the national) past on the other. The pervasiveness of war memory as a form of national and state-driven communication, in fact, might suggest that no topic would spark off narratives that touch on the dynamic relationship between individual and nation/state as well as war (Winter 1995). Oral historians emphasise that the narratives which emerge from oral history interviews are not, nor can they ever be, a direct recovery of what the speaker experienced at the time they are describing, even if they are supposed to be offering insight into little-documented settings and events through eyes that witnessed them first-hand. Rather, the interview is an act of narration, often hours-long, which is socially situated and historically contingent. A 90minute interview about a peacekeeper's six-month tour of duty, to say nothing of an interview about a Bosnian linguist's experiences of living through the 1990s war and coming 
to terms with the post-war condition of their country over the course of two decades, will never convey the fullness of a speaker's experience during that time: rather, speakers select from their memories, consciously and subconsciously, in response to an interviewer's questions and in order to present their narrative and self in certain ways rather than others.

These choices are shaped by the social and cultural scripts a speaker has for understanding their experiences and those that they believe their interviewer and their audience may have: a speaker's expectations about what the public understand about the war they were involved in often shapes what they say or keep to themselves. Thomson, for instance, found that, once sustained anti-militarist challenge had broken the hegemony of the 'Anzac legend' in Australian public memory (that is, the hegemony of the idea that Australian troops had shown nothing but courage and mateship during the First World War and had returned to Australia bound together as a nation), Anzac veterans were able to speak of wartime experiences which broke that mould in ways they had not been able to articulate before: it was easier for the public or loved ones to understand their more difficult narratives in the 1980s, they often thought, compared to earlier in their lives (Thomson 1994). Conversely, perceptions of the public's lack of understanding about a war, or an aspect of wartime experience, may sometimes be what motivates interviewees to take part in a research project and go on record: several Bosnian interpreters interviewed for Languages at War, for instance, mentioned in their interviews that they had wanted to take part because interpreters' work had been crucial to the activities of the peacekeeping missions and yet - in Britain and in Bosnia - they had been forgotten. Among the reasons why a possible interviewee does not take part, meanwhile, can be that they do not trust the researcher, or the (immediate and structural) institutions the researcher represents, to convey their experiences accurately: a knowledgeable and empathetic interviewer can mitigate but never completely overcome this possibility.

Even the most informative interviews in the Languages at War collection, on which we depended to be able to find out about the professionalization of the language service at NATO's Sarajevo headquarters or the origins of British military 'Serbo-Croat' training at the Defence School of Languages were also, as this chapter argues, narratives. The tension between fact and narration, between information about the past and narrative produced in the present, between what there is to interpret and how the interviewer can interpret it, is what constitutes the interview as a distinctive form of source anyway, and perhaps all the more so in researching the conjunction between two topics as inextricably linked to memory - and to the relationship between individuals and collectives - as war and language are. Whether it is possible to find out about materials and policies that might not have been written down or kept to the fullest extent at the same time as finding out, in as much depth as possible, how interviewees were negotiating the multiple identities of a language intermediary or any other language user in a conflict zone and how they were narrating them at the moment of interview, is a methodological reservation that every researcher using interviews will have to negotiate: within an interdisciplinary project, we were able to alleviate it to some extent by striking different balances in publications aimed at different disciplinary communities. There are still decisions to be made in any interview-based project about how far one is interested in interview as narrative and how far one is interested in the content of the interview as fact.

Designing and conducting interviews on languages and war

Researchers planning to use interviews in studying languages at war have the benefit of a breadth of methodological guides in the humanities and social sciences: their advice, applicable across disciplines, can be combined with the insights into the distinctive features of this conjunction of topics that works such as this handbook provide. Most qualitative research methods handbooks (see, e.g. Denzin and Lincoln (ed.) 2017) contain at least one 
chapter on interviewing, possibly more: for instance, some handbooks would distinguish 'elite interviewing' of officials and experts from interviews with members of the public (a distinction that a languages-and-war project might, or might not, wish to make - ours designed specific questions for interviewees who had held key roles in the history of peacekeeping language support but still worked these into the biographical structure we used for interviews in general). Other manuals are dedicated entirely to qualitative interviewing, especially but not solely as used in sociology and education (e.g. Wengraf 2009; Olson 2011; Gubrium et al. (ed.) 2012; Edwards and Holland 2013; Seidman 2013; Mann 2016; Fujii $2017^{3}$ ) - these can be very helpful at the beginning of a project in deciding what approach to interviewing will best suit the research. Oral history literature, meanwhile, combines useful practical advice for designing and arranging interview projects with conceptual discussions of themes such as narrative, memory and intersubjectivity which - as this chapter argues - are worth considering even for researchers who choose to use interviewing more for informationgathering than narrative analysis (see Bryson and McConville 2014; Yow 2015; Abrams 2016; Thompson and Bornat 2017).

Both 'semi-structured' and 'biographical' forms of interview, as methods literature often calls them, are well suited to languages-and-war research. A semi-structured interview will pose questions that the researcher has designed in advance to find out about their research questions (requiring the researcher to translate ideas that derive from their own conceptual frameworks into interview questions that use lexis and concepts from the interviewee's lifeworld), with flexibility to ask spontaneous follow-up questions so that an interviewee can expand on a matter of interest they did not discuss in much depth. (Structured interviews, in contrast, pose the same set of questions in order to all participants and do not involve individualised follow-ups - essentially a spoken questionnaire.) Biographical interviewing uses questions that guide the interviewee through narrating the various stages and experiences of their life (the first is likely to be 'Can you tell us when and where you were born?') and is most effective when the interviewer already knows the main contours of the interviewee's biography (the IWM, for instance, has a pre-interview military service record sheet where interviewees will write down their different tours of duty so that the interviewer knows what to ask about - though civilians' experiences, even in military language training or peacekeeping, did not fit neatly into this schema).

The Languages at War interviews blended these approaches. Gathering insights into the language practices of peacekeeping from both sides of the translation/interpreting relationship - the foreign language and the local language (a divide that mapped on to the 'international' and 'local' divide (see Mac Ginty 2011) in the study of peacebuilding) - meant we structured the interview collection around ex-peacekeepers (and civilians connected to the multinational UN/NATO force) in the first year and former locally-recruited interpreters in the second year. Our announcements seeking participants received most positive responses when they reached networks of people who felt that their experiences related to languages and peacekeeping had not been heard before and they had something to say, whether these were Army educators who had been instrumental in developing crash-course 'Serbo-Croat' training when Britain first committed troops to Bosnia, ex-interpreters who wanted to speak of their continued ties to Britain or their dissatisfaction with how the British Army had supported its local employees, or NCOs and officers who were advocating for language skills to be better recognised in military career progression and as factors in operational effectiveness. Certain regions of $\mathrm{BiH}$, particularly Sarajevo, the Vitez/Travnik area of central Bosnia (where most British troops had served during the war) and the vicinity of Banja Luka (the headquarters of

\footnotetext{
${ }^{3}$ The handbook by Lee Ann Fujii (2017) may be particularly helpful as the author is a specialist on mass violence and genocide in $\mathrm{BiH}$, Rwanda and the USA.
} 
the British-led division of the postwar NATO force), were better represented in the eventual set of interviews than others. ${ }^{4}$ For our purposes, this did not matter; if however our research questions had required more systematic comparisons between the three NATO divisional areas, we would have needed to plan another period of fieldwork to compensate, including time making the connections in Mostar that some participants helped to make for us in Banja Luka by forwarding my announcement through their existing networks to each other. ${ }^{5}$

The encounters and incidents I asked people to recall in interviews produced very informative accounts of the construction and fixedness/blurredness of professional identities in the changeable contexts of language support for multinational peacekeeping missions, though only up to a point: interviews are poor instruments for accurately obtaining dates or financial data such as rates of pay (Brownlie 2017: 13). Like Louise Askew and Ian Jones, whose study of NATO operational language support in $\mathrm{BiH}$, Kosovo and Afghanistan placed one of the case studies we had covered for Languages at War (the professionalization of NATO's headquarters language service for Sarajevo and the HQ's other offices in $\mathrm{BiH}$ ) in the context of NATO's evolving need to provide language services for increasingly complex and dangerous coalition operations (Jones and Askew 2014), I had to manage the implications of an interviewee sometimes having been the only person who had performed a particular role at a particular place and time: providing too much contextual information in discussing their interviews might identify them, yet excising too much would make it more difficult to draw the granular conclusions about changes in policy and practice over time - and variance across areas and command structures - that we needed to do. Where ambiguous, researchers should err on the side of protecting confidentiality and anonymity ${ }^{6}$ - though equally, researchers expecting to be publishing interview extracts anonymously may encounter interviewees who want their role in events to be recorded and ask for their real name to be used.

The Languages at War interviews, after a few iterations, stabilised into a two-part, first biographical and then more targeted, structure. At the beginning of the interview, I explained that I would ask interviewees questions that took them through their memories chronologically and would then ask further questions about topics the project was going to be interested in. The first part of the interview thus used biographical questioning to guide the interviewee through a narrative of their prior involvement with languages, translation and interpreting, their coming to serve on a UN/NATO base in Bosnia (whether as a foreign peacekeeper or a locally-recruited language worker), and their experiences while there. We had also developed a question guide for semi-structured interviewing, based on topics from Translation and Interpreting Studies and the cultural history of war that would contribute to answering the project's research questions (here for instance I had included one or two questions that would probe how foreign interviewees had formed their preconceptions of

\footnotetext{
${ }^{4}$ In particular, there ended up being no interviews with locally-recruited interpreters who had worked in another of the three Multi-National Divisions of the NATO force, the French-led division headquartered in Mostar (one or two potential participants from Mostar contacted me, but were away when I was visiting Bosnia or did not respond).

${ }^{5}$ In fact, the over-representation of Banja Luka compared to Mostar had its advantages in that Mostar has been very heavily studied by peacebuilding researchers as an example of a post-war city that continues to be ethnically divided. There were fewer studies of Banja Luka (though see, e.g. Stefansson 2006), and fewer still that viewed the area through the lens of postsocialist and post-war socio-economic precarity which emerged through my interviews there and elsewhere as a major theme for understanding the experiences of locallyrecruited interpreters across Bosnia. Mostar's high profile as a site for peacebuilding research might well have left residents there with greater 'research fatigue', making them less likely to want to take part in yet another project (on 'local tactics of resistance' to research where most knowledge production is primarily to the benefit of the outside researcher, see Kappler 2013).

${ }^{6}$ One article on conflict interpreting by Rebecca Tipton (2011) based on an interview with an Iraqi interpreter who worked for the US Army, for instance, does not provide any localising information beyond the type of unit the interpreter worked for (civil affairs) and the broad region (southern Iraq).
} 
Bosnia and the conflict before they arrived there). Each interviewee touched or did not touch on a different range of these during their biographical narrative. In the second part of the interview, I asked follow-up questions about these topics that either expanded on stories they had told or introduced the topic as a new one, depending on what they had said in the first part - the aim was for each interview to have collected responses about each item on the question guide.

A few interviews, by serendipity rather than design, also included a third section based on photo elicitation. Though we had not designed photo elicitation into the methodology and I had not even anticipated that it could be useful (not having used it before), some interviewees asked to bring along photo albums to 'jog their memory' and then offered to talk through the photographs on tape. This produced rich and seemingly enjoyable narratives where interviewees could reminisce about the sites and people in the photographs and show me what they wanted me to perceive about the material settings where incidents in their interviews had taken place. As with their biographical narratives, I was able to ask follow-up questions about the photographs by thinking back to topics from the question guide. Photo elicitation (plus video elicitation and object elicitation) is itself an established interview methodology, where the visual stimulus can evoke remembering in ways that spoken questions do not (Harper 2002), and could very well be used systematically in a languagesand-war project: indeed, Rachel Woodward and Neil Jenkings - geographers whose interest in military personnel's narratives of place and space shares much common ground with the interest in intercultural encounters in languages-and-war research (Woodward and Jenkings 2012) - used photo elicitation extensively in research with British military veterans who had served in Iraq and Afghanistan (Jenkings, Murphy and Woodward 2016).

The flexible and dynamic approach of these interviews was most certainly a co-production of narrative, especially when a question elicited a response such as 'I hadn't thought about that' - the active remembering that a speaker would then engage in as they answered the question represented their putting together different aspects of their knowledge for the first time, which they would not have thought about if not for the interview. Interviewing therefore involves the researcher in actively producing their source material more than any other historical methodology, and (through its one-to-one subjectivity) differently to methods such as autoethnography or creative practice. This is a powerful instrument for researchers of matters such as languages and war where the concepts one is most interested in might not even have been conceptualised by the relevant organisations or individuals as things which could be known about.

At the same time, the intersubjectivity of the interview as the interviewer encourages reflection in particular directions also creates risks: posing a question through a frame that is very distant from - or, worse, conflicting with - an interviewee's own self-narrative of their experience can impede understanding or even lead to the interviewee pushing back against the questions. In my own interviews, I was conscious that I did not want to turn the research into another project 'about ethnicity' in Bosnia, since I had argued in other work that the frame of ethnicity had been over-emphasised in studies of the Yugoslav wars: I therefore tried to avoid framing Bosnian interviewees as ethnic subjects in my questions, addressing them primarily through their technical and professional identities instead. This permitted many interviewees to speak in more complex terms about how they had negotiated wartime and post-war ethnopolitics than questions which addressed them primarily as Bosniaks/Muslims, Serbs or Croats would have done, but left at least one Bosniak interviewee who did wish to narrate himself as an ethnic subject without sufficient space to do so, and only after the interview did I realise how badly our frames had clashed and how slow I had been to understand what was going on (Baker 2015). The length of time it took me to recognise what had happened illustrate how important it is for interviewers to engage in 
their own reflective practice between interviews (Roulston 2011), but also how social positionality - and how researcher and interviewer are positioned in relation to each other can dramatically effect the course of an interview.

Positionality and social identity in interviews

Recognising and accounting for dynamics of positionality - the social identities and lived experiences of both interviewee and interviewer, and how these shape the dynamics of the narrative they co-produce - is an essential step in interpreting the record of every interview. Interviews do not take place outside the structures of power and marginalisation that permeate society: they are as embedded in them as any other interpersonal interaction, with the added power imbalance that the researcher wishes to gain knowledge - often of a personal and emotionally significant nature - from the interviewee and will use it for purposes that usually benefit the researcher more than the interviewee. Some oral historians working with marginalised communities will design their projects as 'action research' that identifies and works to change problems the community identifies through their interviews, and other projects emerge organically grounded in community advocacy work; the traditional academic interview-based research project usually has the greatest distance and imbalance between researcher (as a representative of their institution) and interviewer to negotiate.

Both the social identities that interviewers and interviewees share, and the social identities that they do not, strongly influence the dynamic of an interview, as does the matter of which parties belong to a majority or a minority in which ways, and the hierarchical social relations of privilege in which these identities exist. Every category of social identity presents an axis along which the researcher and interviewee may be more similar or more different, including gender, race, ethnicity, nationality, age, religion, sexuality, disability, relationship towards their gender identity, political beliefs, and whether or not the researcher has lived or worked in the same social settings as the interviewee, especially in settings such as the military where membership or non-membership is itself a social identity. Commonly, the researcher will share some identities with the interviewee but not share others. Their positionality relative to each other will therefore be the product of how their places on all these axes of identity intersect (see Collins and Bilge 2016). The domains in which the researcher comes from a more privileged social group, or has not experienced a stigma or trauma that is important to the interviewee's narrative, are often those that affect the interview most - white women interviewing women of colour, in particular, may begin a project expecting their shared gender will automatically build rapport, then discover they must work harder before interviewees will trust them to understand and validate narratives of racism that interviewees have experienced but the interviewer has not.

This is not to suggest that researchers must necessarily be as close to their interviewees' backgrounds as possible to be able to establish rapport with each other. In fact when there is too much shared knowledge between researcher and interviewee (a potential drawback in projects where researchers are interviewing former colleagues or have a shared educational or institutional background), an interviewer must work skilfully to make sure that knowledge both parties take for granted is still explained on tape to make the narrative intelligible, without forcing the interviewee into exposition in an unnatural way. Some of the richest interviews are precisely those where the researcher has been able to build a strong enough relationship of trust that the interviewee has confidence in narrating their experience to someone who did not live through it: there is no substitute for deep, well-informed and empathetic listening in bringing this about.

Another dimension of social identity that can affect any interview, but is particularly marked in language-related research, is the first language of each party and any other 
language competences they have (see Temple 1997; 2002). Both of these - and the status of each language in global language politics - feed into the power dynamics of identity performance, knowledge production and language choice that occur when researchers and interviewees negotiate which language to record the interview in. If both parties speak different first languages, they will be speaking during the interview from different levels of competence. Choosing the interviewee's first language may let them speak more fluently and therefore more freely, but places the onus and power of translation on the researcher. Using the researcher's first language, especially if this is English, gives the interviewee greater control over how their meaning will be recorded, but may impose greater pressure or cause an interviewee to hold speech back because they feel less confident in their expression; the researcher will also have to decide how far to convert the transcript to standard English, a choice with wider politics of representation surrounding it (Temple 2005).

Since the requirements for my post with Languages at War included the ability to conduct interviews in Bosnian/Croatian/Serbian (BCS), and I had conducted interviews in Croatian during my $\mathrm{PhD}$ research), I could offer ex-interpreters the choice to record the interview in 'my language or yours'. 'To my surprise, they all chose English except one person, who I had been introduced to via a former language teacher. Being able to produce an extended narrative in English was a sign of professional competence, and to produce it in conversation with a native speaker of English (and of British English) was an opportunity that exinterpreters who had worked for the British-led NATO division had had less often since the UK withdrew most troops from Bosnia in 2004. Moreover, the specialist military vocabulary that interviewees might wish to use in their narratives was often vocabulary they had only known in English. Women interpreters, and men who had not served in local armed forces before or during the war, would have been unlikely to encounter all these terms and their meanings in civilian life, likewise men who had become interpreters during the war rather than join or be conscripted into one of the local armed forces. ${ }^{8}$ Even men with some military experience (such as one Bosniak man who had completed two years at Yugoslav military academy before the war) would not have known all this vocabulary in both languages without a glossary, if for instance it was specialised to NATO or had not had an exact equivalent in NATO military doctrine. Local interpreters therefore acquired the military vocabulary - and military slang - of the forces they worked for, meaning that they might not have been able to narrate their language encounter memories in their first language without having to stop and find equivalents for the terms they only knew in English. They were well aware, at the same time, that the commercial and imperial history of Anglophone powers had given my first language far greater global power and reach than theirs. Likely for all these reasons, all but one interpreter chose to record the interview in English - even when sometimes we had been chatting in Bosnian before the interview began.

The practicalities and politics of language choice in languages and war research present just one example of how the positionality of researchers relative to their interviewees establishes the conditions for an interview. Such questions of positionality are essential to consider in any interview project - but take on extra dimensions in research about war and

\footnotetext{
7 The phrase 'naš jezik' ('our language') among speakers of the language(s) formerly called Serbo-Croat is an established convention to avoid having to fix one national or politicised name on to the language and potentially disrupt the community of 'we' in a conversation if the speaker's choice of name turns out to harden a boundary between themselves and another. 'My language or yours?' is a much more flexible way for an Anglophone to negotiate language choice in former Yugoslavia than, e.g. 'English or Bosnian?'

${ }^{8}$ Beyond the financial benefits that working for a foreign military force which paid in hard currency had in a wartime economy, working as an interpreter and avoiding military service might have particularly appealed to men who were part of pacifist and alternative cultural circles, of mixed ethnic background, gay or bisexual - all of whom could expect an ethnonational military force to be an unwelcome environment.
} 
the military because of the valences of 'military'/'civilian' distinctions and the very subject matter of war (Williams et al. (ed.) 2016).

'Military' and 'civilian' identities in interviews on languages and war

The boundary of 'military' or 'civilian' identity is another axis of belonging that heavily influences whether researcher and interviewee will appear as insiders or outsiders to each other, and their relative positions in this respect can be expected to have a bearing on what and how an interviewee chooses to explain. The problem of how far direct experience of war can be communicated to a civilian who has not experienced it (see Dyvik 2016) underpins military memoirs and war literature, films and television dramas about war and the military, and troops' and veterans' interactions in everyday life, and therefore hangs also between an interviewee with military experience and a civilian interviewer (since, in this respect too, the interview does not exist outside broader social dynamics). A serious research interview is unlikely to fall into the trap of the prurient, insensitive questions from curious civilians that most frustrate soldiers and veterans, but will still be shaped by what reactions an interviewee has already learned to expect on broaching (or not feeling able to broach) truths of their military experience that they expect to be unintelligible or unpalatable to a civilian listener such as missing the sensations of being under fire (Hennessey 2009). At the same time, many military personnel have not served in combat roles and have had strikingly different everyday lives in the military from what civilians whose only encounters with the military have been through media might expect.

Beyond the boundary of 'civilian' and 'military', another shared or unshared factor in interviews about war is the embodied and visceral experience of being in a conflict zone. Someone need not have been in the military to have gained this first-hand understanding: civilians from the area of the conflict, and foreign civilians such as journalists or aid workers who had been present there, would also share it, from different perspectives grounded in what 'danger', 'security', and the capacity to leave had meant to each of them. Communicating such memories to an interviewee who has (as I have) led a comfortable peacetime life requires an intense and emotional process of remembering in order to bring them to the surface, before they can be vocalised: speaking to an interviewer across this interpersonal barrier gives the encounter a different tone from speaking in the knowledge that the interviewer's own embodied memory will be giving them a reference point from which to comprehend the scene an interviewee might not be setting through their words. This is not to suggest, however, that interviewers who have experienced the military or war at first hand will automatically obtain richer interviews about languages and war than those who have not. Awareness of one's own personal lack of military experience, Stephen Atherton (2016: 251) suggests on the basis of his interviews with military men about military domestic spaces, forces a researcher to be reflexive about their positionality in a way that can and should then extend to considering how their other social identities and the other aspects of their interviewees' social identities shape the interview.

The gradations of civilians' connections to or distance from the military and war are, moreover, complex. The closest circle contains partners and family members of service personnel and veterans, who as interviewers may have more shared knowledge in common with military interviewees than with other civilians when it comes to the emotional and everyday dimensions of military life (Jervis 2016: 170); many more civilians have family histories deeply influenced by ancestors' and relatives' military service and/or have lived in heavily militarised towns. ${ }^{9}$ This continuum of experiencing war (see Sylvester 2013) can start

\footnotetext{
${ }^{9}$ Interviewers may even find they remember more of these connections, or talk more about them, as they get to know interviewees. I am quite sure that I referred to my grandfather's wartime service as a Royal Air Force pilot in conversation with several British (ex-)military interviewees (and would have liked to have been able to
} 
to be a basis for empathetic listening. An interviewer's positionality towards war and the military may also emerge into the psychodynamics of the interview in ways that, before the project or the encounter, they did not expect, through processes of 'transference and countertransference' that psychotherapists who practice deep listening are trained to recognise but oral historians and other qualitative interviewers often are not (Jessee, in press: 16). ${ }^{10}$ Researching military topics will almost certainly, sooner or later, force researchers to confront their family histories of engagement or disengagement with war and the military, their own imaginations of war and conflict within the cultural imaginaries to which they have belonged (see Dawson 1994), their own experiences of any military or semi-military service, and the ways in which the 'militarization' (Enloe 2000) of wider society has involved them personally (Baker et al. 2016). The intersubjectivity of interviewing and deep listening may bring such memories and (dis)identifications to the surface more than any other research method except ethnography, where the researcher's body is directly present in militarised material spaces - yet since certain interviews also, less immersively, take the researcher into such spaces, the ways in which researchers use their senses to gather knowledge in ethnography and interviewing are not completely separate.

In languages and war research, however, the military-civilian relationship (which may either be a point of affinity or distance) is not the only theme mediating the interviewerinterviewee relationship: another is each party's interest in languages, which may often be a hinge of rapport for the interview however asymmetric the relationship between them is in other ways. The opportunity for an interviewee whose experience of war involved something significant about language - a conjunction which has very little public awareness and used to have very little institutional awareness before the post-9/11 turn to recognising languages and cultural knowledge as a tool in counter-insurgency - of which there is very little public awareness, or often even (outside specialist language services) institutional awareness - to narrate their perspective on it to an interviewer (and research institution) that has acknowledged it as meaningful and will ask about it knowledgeably may well be part of what persuades an interviewee to respond positively to an invitation for participation. I was anxious when Languages at War began that the combination of my age, gender, and the inferences about my politics and sexuality that interviewees might draw from my appearance could lead to some participants taking me less seriously as an interviewer. In fact, since my $\mathrm{PhD}$ was in language-based area studies and I spoke fluent BCS, the position that many of the military interviewees found where we could speak as equal participants in a community of practice was that of linguist (especially, but not only, when 'linguist' or 'educator' was also part of their professional identity). Whiteness, and the signals my accent sent about social class, then compensated for the elements of my identity I feared would create most difference between myself and senior military officers (the interviews that made me most nervous). Meanwhile, my linguistic fluency and the months I had spent living in the wider Yugoslav region (mainly in Zagreb) during my $\mathrm{PhD}$ helped to give Bosnian interviewees who spoke to me confidence that I would have a deeper understanding of the context for their experiences, though it was not (and I would not claim it to be) the equivalent of having lived in Bosnia before or having had the war affect my home town or my family.

remember more about his squadron, plane and dates of service - the waymarkers that structure military narratives) - though the positions I could speak from in conversations like those would have been very different if my grandfather had been, say, a Kenyan or Cypriot rebel who had fought against the British.

${ }^{10}$ For instance, my father is left-wing and was active in the labour movement in London in the early 1970s, when it has long been rumoured a right-wing faction in the British establishment was plotting a military coup: at one point during an interview with a man whose military career had passed through Army intelligence during the 1970s it occurred to me (and I had to struggle not to give away that something had interjected itself into my thoughts while I was supposed to be listening) that this man or someone like him might have faced my father across an interrogation table if such a coup had gone ahead. 
Most interviews are not, therefore, simply a matter of interviewing as an insider or an outsider. Interviewers will often be speaking to their interviewee as an insider in some ways and an outsider in others - indeed an interviewee may even address them as an insider when they consider themselves an outsider to the 'we' that the speaker is drawing them into (such as when my Britishness and whiteness might have suggested to some British interviewees that I shared what seemed to me to be their more simplified and distanced interpretation of the causes of violence in Bosnia). The binary categories of 'military' and 'civilian' hide a wider spectrum of ways in which war and the military have shaped people's experience. The military does not produce one single military subjectivity but many, depending on gender, rank, class, service branch, and regiment - the arms furthest from combat (the 'combat service support' arms in British military nomenclature), marginalised in much of the public presence of war, deserve as much consideration as the combat arms when researching concepts such as the production of 'military masculinities' (Woodward and Jenkings 2011: 255), and these are the arms to which some of the military interviewees most likely to be interviewed about languages and war (career military linguists and language teachers) belong.

The study of languages and war simultaneously destabilises - like much contemporary research on war - the category of 'civilian'. Military language work commonly embeds civilians into militarised spaces far more intimately than they would otherwise be (locallyrecruited field interpreters in Bosnia often lived on foreign military bases, and even wore unmarked foreign uniforms, during the war and for some years afterwards, for security as well as practicality), often leaving them with significant identity conflicts to work through if they or those around them do not sympathise with the aims or behaviour of the force that is employing them. The field of languages and war research therefore has potential to expand scholars' - and the public's - understanding of the military/civilian divide, and of how experiences of war permeate beyond the military, in original ways, as well as helping to extend research on experiences within the military (such as the production of 'military masculinities') by bringing towards the centre military subjectivities other than the combat soldier (see Chisholm and Tidy 2017).

The narratives obtained through interviewing in languages and war research, therefore, are simultaneously the source of invaluable factual knowledge, which often could not be easily obtained through any other method, and intersubjectively co-produced narratives of war indeed, intersubjectively co-produced narratives about people's identity in war. This duality is inherent to interview-based methodology, since narrative itself is both a communication of identity to others and, more personally, a means of making sense of one's identity for oneself. It would be particularly perceptible in interviews about languages from any perspective, since language both narrates and communicates identity. Yet in another respect, research on languages and war differs from research on topics and themes that the researcher does not consider to be militarised: war and the military are institutions to which hardly anybody is politically neutral. Research-based knowledge that improves military effectiveness ultimately improves the effectiveness of an institution which exists to use lethal force where necessary in achieving the objectives of the state to which it belongs. The ethical considerations of language research related to war and the military are in this sense even greater than those surrounding other fields of language research. None of the ethical, political, intersubjective, and narrative complexities should deter researchers on languages and war from using interviews, even if their primary purpose is reconstruction rather than analysis. Successfully using interviews even for more fact-finding purposes, however, still entails understanding how narrative, identity and memory operate in the interview setting, and how the dynamics of interviewing are conditioned by the context of researching languages and the context of researching war. 


\section{References}

Abrams, Lynn. 2016. Oral History Theory. 2nd ed. London and New York: Routledge. Atherton, Stephen. 2016. 'Researching military men'. In The Routledge Companion to Military Research Methods, ed. Alison J Williams, K Neil Jenkings, Matthew F Rech and Rachel Woodward: 243-55. London and New York: Routledge.

Baker, Catherine. 2011. 'Have you ever been in Bosnia? British military travelers in the Balkans since 1992'. Journeys 12 (1): 63-92.

Baker, Catherine. 2015. 'The frames we use: narratives, ethnicity, and the problem of multiple identities in post-conflict oral histories (Bosnia-Herzegovina)'. In Beyond Testimony and Trauma: Oral History in the Aftermath of Mass Violence, ed. Steven High: 285-310. Vancouver: UBC Press.

Baker, Catherine. 2016. 'Writing about embodiment as an act of translation'. Critical Military Studies 2 (1-2): 120-4.

Baker, Catherine, Victoria Basham, Sarah Bulmer, Harriet Gray and Alexandra Hyde. 'Encounters with the military: towards a feminist ethics of critique?' International Feminist Journal of Politics 18 (1): 140-54.

Baker, Mona. 2006. Translation and Conflict: a Narrative Account. London and New York: Routledge.

Brownlie, Siobhan. 2017. 'Institutional memory and translating at the DGT'. The Translator 23 (1): 1-16.

Bryson, Anna, and Seán McConville. 2014. The Routledge Guide to Interviewing: Oral History, Social Enquiry and Investigation. London and New York: Routledge.

Chisholm, Amanda, and Joanna Tidy. 2017. 'Beyond the hegemonic in the study of militaries, masculinities, and war'. Critical Military Studies 3 (2): 99-102.

Coffey, Simon. 2010. 'Stories of Frenchness: becoming a Francophile'. Language and Intercultural Communication 10 (2): 119-36.

Collins, Patricia Hill, and Sirma Bilge. 2016. Intersectionality. Cambridge: Polity.

Daughtry, J Martin. 2015. Listening to War: Sound, Music, Trauma, and Survival in Wartime Iraq. Oxford: Oxford University Press.

Dawson, Graham. 1994. Soldier Heroes: British Adventure, Empire, and the Imagining of Masculinities. London and New York: Routledge.

Denzin, Norman K, and Yvonna S Lincoln (ed.). 2017. The Sage Handbook of Qualitative Research. 5th ed. London: Sage.

Dyvik, Synne L. 2016. 'Of bats and bodies: methods for reading and writing embodiment'. Critical Military Studies 2 (1-2): 56-69.

Edwards, Rosalind, and Janet Holland. 2013. What is Qualitative Interviewing? London: Bloomsbury Academic.

Enloe, Cynthia. 2000. Maneuvers: the International Politics of Militarizing Women's Lives. Berkeley, CA: University of California Press.

Fujii, Lee Ann. 2017. Interviewing in Social Science Research: a Relational Approach. London and New York: Routledge.

Gubrium, Jaber F, James A Holstein, Amir B Marvasti and Karyn D McKinney (ed.). 2012. The Sage Handbook of Interview Research: the Complexity of the Craft. 2nd ed. London:

Sage.

Hammond, Andrew. 2007. The Debated Lands: British and American Representations of the Balkans. Cardiff: University of Wales Press.

Harper, Douglas. 2002. 'Talking about pictures: a case for photo elicitation'. Visual Studies 17 (1): 13-26. 
Hennessey, Patrick. 2009. The Junior Officers' Reading Club: Killing Time and Fighting Wars. London: Allen Lane.

Jenkings, K Neil, Ann Murphy and Rachel Woodward. 2016. 'Photo-elicitation and military research'. In The Routledge Companion to Military Research Methods, ed. Alison J Williams, K Neil Jenkings, Matthew F Rech and Rachel Woodward: 345-57. London and New York: Routledge.

Jervis, Sue. 2016. 'Psychoanalytically informed reflexive research with service spouses'. In The Routledge Companion to Military Research Methods, ed. Alison J Williams, K Neil Jenkings, Matthew F Rech and Rachel Woodward: 167-79. London and New York: Routledge.

Jessee, Erin. In press. 'Managing danger in oral historical fieldwork'. Oral History Review. https://doi.org/10.1093/ohr/ohx038 (accessed 20 July 2017).

Jones, Ian, and Louise Askew. 2014. Meeting the Language Challenges of NATO Operations: Policy, Practice and Professionalization. Basingstoke: Palgrave Macmillan.

Kappler, Stefanie. 2013. 'Coping with research: local tactics of resistance against (mis)representation in academia'. Peacebuilding 1 (1): 125-40.

Kelly, Michael, and Catherine Baker. 2013. Interpreting the Peace: Peace Operations, Conflict and Language in Bosnia-Herzegovina. Basingstoke: Palgrave Macmillan.

Mac Ginty, Roger. 2011. International Peacebuilding and Local Resistance: Hybrid Forms of Peace. Basingstoke: Palgrave Macmillan.

Mann, Steve. 2016. The Research Interview: Reflective Practice and Reflexivity in Research Processes. London: Palgrave Macmillan.

Olson, Karin. 2011. Essentials of Qualitative Interviewing. London and New York:

Routledge.

Rafael, Vicente L. 2012. 'Targeting translation: counterinsurgency and the weaponization of language'. Social Text 30 (4): 55-80.

Roulston, Kathryn. 2011. Reflective Interviewing: a Guide to Theory and Practice. London: Sage.

Seidman, Irving. 2013. Interviewing as Qualitative Research: a Guide for Researchers in Education and the Social Sciences. 4th ed. New York: Teachers College Press.

Stefansson, Anders H. 2006. 'Homes in the making: property restitution, refugee return, and senses of belonging in a post-war Bosnian town'. International Migration 44 (3): 115-39.

Summerfield, Penny. 1998. Reconstructing Women's Wartime Lives: Discourse and Subjectivity in Oral Histories of the Second World War. Manchester: Manchester University Press.

Svoljšak, Petra. 2012. 'The language policy of the Italian army in the occupied Slovenian territories, 1915-17'. In Languages and the Military: Alliances, Occupation and PeaceBuilding, ed. Hilary Footitt and Michael Kelly: 70-85. Basingstoke: Palgrave Macmillan. Sylvester, Christine. 2013. War as Experience: Contributions from International Relations and Feminist Analysis. London and New York: Routledge.

Temple, Bogusia. 1997. 'Watch your tongue: issues in translation and cross-cultural research'. Sociology 31 (3): 607-18.

Temple, Bogusia. 2002. 'Crossed wires: interpreters, translators, and bilingual workers in cross-language research'. Qualitative Health Research 12 (6): 844-54.

Temple, Bogusia. 2005. 'Nice and tidy: translation and representation'. Sociological Research Online 10 (2). http://www.socresonline.org.uk/10/2/temple.html (accessed 20 July 2017).

Thompson, Paul, and Joanna Bornat. 2017. The Voice of the Past: Oral History. 4th ed. Oxford: Oxford University Press. 
Thomson, Alistair. 1994. Anzac Memories: Living with the Legend. Melbourne: Oxford University Press.

Tipton, Rebecca. 2011. 'Relationships of learning between military personnel and interpreters in situations of violent conflict: dual pedagogies and communities of practice'. The Interpreter and Translator Trainer 5 (1): 15-40.

Todorova, Maria. 2009. Imagining the Balkans. New ed. Oxford: Oxford University Press. Venuti, Lawrence. 2008. The Translator's Invisibility: a History of Translation. 2nd ed. London and New York: Routledge.

Wengraf, Tom. 2009. Qualitative Research Interviewing: Biographic Narrative and SemiStructured Methods. London: Sage.

Wibben, Annick T R. 2011. Feminist Security Studies: a Narrative Approach. London and New York: Routledge.

Williams, Alison J, K Neil Jenkings, Matthew F Rech and Rachel Woodward. 2016. The Routledge Companion to Military Research Methods. London and New York: Routledge. Winter, Jay. 1995. Sites of Memory, Sites of Mourning: the Great War in European Cultural History. Cambridge: Cambridge University Press.

Woodward, Rachel, and K Neil Jenkings. 2011. 'Military identities in the situated accounts of British military personnel'. Sociology 45 (2): 252-68.

Woodward, Rachel, and K Neil Jenkings. 2012. "This place isn't worth the left boot of one of our boys": geopolitics, militarism and memoirs of the Afghanistan war'. Political Geography 31 (8): 495-508.

Yow, Valerie Raleigh. 2015. Recording Oral History: a Guide for the Humanities and Social Sciences. 3rd ed. Lanham, MD: Rowman and Littlefield. 